\title{
Getting Prepared: Employee Readiness for Changes
}

\author{
Muhammad Faris Abdurrohman ${ }^{1}$ and Anissa Lestari Kadiyono ${ }^{1}$ \\ \{m.farisabdurrohman@gmail.com, anissa.lestari@unpad.ac.id\} \\ ${ }^{1}$ Lecture at Padjadjaran University, Indonesia
}

\begin{abstract}
Considering the development of current global economy, every organization is required to continue to adapt and make changes to the progress of their organization. Changes made by the company require the management to prepare their employees to make some changes that are expected to be successfully implemented. This research was conducted to identify what employees need to prepare to deal with changes. Respondent in this research were 92 employees who have worked for at least 1 year in the head office and the factory of manufacturer and distribution of veterinary drugs in Bandung city which is currently experiencing a change in business direction and implementing new strategies. This research data was obtained through questionnaire method. The questionnaire used in this study was a readiness for changes questionnaire to measure employee's beliefs, attitudes, and intentions towards changes that occur. Data were analyzed quantitatively through descriptive statistical analysis. The result of this study showed that employees have not reached the condition of complete readiness to deal with changes that occur in the company. It indicates that there are other findings showing that dimensions of beliefs have a significant contribution to employees' readiness for changes.
\end{abstract}

Keywords: Readiness for Changes, Beliefs, Intentions, Attitudes, Employee

\section{Introduction}

The current global economic development increases competition among companies to become the best one in their fields. This competition requires each company to make organizational changes by adapting and adjusting organization-al needs. Organizational change is carried out by the company to maintain its existence and create a better organizational development. Organizational change is a process of moving from the current condition to conditions expected by an organization in order to increase its effectiveness (Jones, 2013). If a company does not make changes properly, the company will not be able to optimize the effectiveness of its organization. Thus, the company cannot compete in global economic development and will possibly threaten the existence of the organization (Kunert and Staar, 2018),

The employee readiness for changes is the key to the success of an organizational change made by the company. If employees are not ready to face the changes, they will not be able to follow and will feel burdened with the organizational changes that occur(Hanpachern, Griego and Morgan, 1998). Lack of attention from the company in understanding the processes that occur in employees causes the company to lose the opportunity to influence employees to be ready to face changes in the company (Rafferty and Restubog, 2006).

Employee's unpreparedness in the face of changes will bring resistance towards the changes that occur. Resistance occurs because an organization cannot provide an effective change process (Vakola, 2013). Therefore, companies need to increase the employee readiness to make changes. The concept of employee readiness in the face of change is expressed by (Armenakis, Harris and Mossholder, 1993) as "A cognitive state comprising the beliefs, 
attitudes, and intentions toward a change effort", which is a cognitive condition consisting of beliefs, attitudes, and intentions towards effort to change.

There are three components forming the employee readiness to deal with changes, namely beliefs, attitudes, and intentions. Beliefs are, the evaluative assessment of the whole individual that he is ready to deal with organizational change that is influenced by an individual's belief that change is needed, that he has the ability to succeed in making changes, and that change will have positive results for his work / role (Armenakis, Harris and Mossholder, 1993). Beliefs are defined as an evaluative assessment of the whole individual that he is ready to deal with organizational changes and is influenced by the individual's belief that change is actually needed, that he has the ability to succeed in making changes, and that change will have positive results for his work/role. (Armenakis, Harris and Mossholder, 1993; Armenakis et al., 2007; Holt et al., 2007) describes five messages of readiness to change as aspects that describe beliefs, namely efficacy, principal support, discrepancy, appropriateness, and personal valence.

- Efficacy is defined as "Confidence in individual and group's ability to make the change succeed (Armenakis, Harris and Mossholder, 1993).

- one's immediate manager, and one's respected peers demonstrate that they support the organizational change." Employees' beliefs that emerge from how their teams and supervisors support the changes that occur (Armenakis et al., 2007).

- Discrepancy is a "justification for why some change was deemed necessary" or employee's belief that changes are important to do(Armenakis et al., 2007).

- Appropriateness is "whether or not the change that is proposed or implemented is the right one for the situation faced by the organization." That is the individual's belief that change will be right for the conditions faced by the organization (Armenakis, Harris and Mossholder, 1993).

- Personal valence refers to the perceived personal benefits (or personal loss) one may reasonably expect as a result of an organizational change" or employee's belief in the equivalent thing he will get based on his efforts towards organizational change (Holt et al., 2007).

(Rafferty, Jimmieson and Armenakis, 2013) proposed definitions of attititudes and intentions. Attitude is a cognitive assessment of individuals derived from the various types of information received about change and becomes an overall evaluative assessment of changes in their role. Intentions are concerned with the motivational factors that influence a behavior and are indicators of how hard a person is willing to try and how much effort he or she is willing to exert in order to perform the behavior[9]. Intentions are motivational factors that influence behavior and are indicators of how hard someone is willing to try and how much effort he wants to make for the changes faced in his job/role. The level of readiness will vary for each employee, it is based on the employee's experience of the balance between the costs and benefits estimated by the employee towards the changes that occur (Vakola, 2014). Hence, the condition of employee readiness to deal with changes will affect the employee behavior to support or resist the changes that occur.

\section{Methodology}

Research design that will be used in this study is a non-experimental with a descriptive approach. The sampling technique that will be used is a non-probability sampling, particularly with a saturation sampling, which is a sampling technique used if all members of the population are used as samples (Sugiyono, 2009). The total number of population in this study 
was 300 employees. The criteria for this research subject is employees who have worked for at least one year in the company. Therefore, the target population in this study was 92 employees. Data collection will be carried out through questionnaire. The questionnaire used was the Readiness for Changes questionnaire as the result of the construction of 31 items measuring employee readiness which was adapted from the Readiness to Change theory proposed by (Armenakis, Harris and Mossholder, 1993). This questionnaire has been tested for validity and reliability with the results of reliability of 0.861 as follows:

Table 1. The questionnaire used

\begin{tabular}{ll}
\hline Dimension & Reliability \\
\hline Beliefs & 0.785 \\
\hline Attitudes & 0.740 \\
\hline Intentions & 0.720 \\
\hline
\end{tabular}

Subjects were comprised of $67 \%$ men, $33 \%$ women, $60 \%$ married, $38 \%$ unmarried, and $2 \%$ divorced. A total of $22 \%$ have worked for 1 year, $35 \%$ worked for $2-5$ years, and $43 \%$ worked for more than 6 years.

\section{Result and Discussion}

The result showed that the cognitive condition of employees was at a high enough level of readiness in the face of change. However, there are still some aspects of change that employees are not ready to face, such as changes in the Standard Operating Procedure (SOP), rules, adaptation of government policies, coordination, job description, facilities, and supervisor control.

Proper understanding of SOP will improve employee readiness in the face of change. This can increase employee awareness of discrepancy towards SOP applied in the company. In terms of the rules, employee resistance can arise because employees do not know or understand the new rules set by the company, hence employees still take disciplinary actions from the regulations in the company. Therefore, consistent submission of the applicable rules needs to be carried out by the company.

While in terms of Government Policy Adaptation, companies need to fully convey government policies that have been adapted. This needs to be done because employee resistance can be caused by them not knowing the government policies that have been implemented in the company. Hence, they do not find the benefits of the policy. Submission of information about government policies adapted by the company can improve employee's personal valence. Viewed from Coordination, with the clear flow of coordination to employees, it will be easier for employees to receive information about what changes need to be prepared.

Job Description is an understanding of employees regarding the standardization of employees in the assignment of responsibilities and tasks for each employee needs to be done by the company. Hence, the efficacy of employees can increase regarding changes in the job description that occur.

Facilities, in order to achieve the expected change goals, the company needs to ensure the availability of facilities that support these changes. When a change is not complemented by the availability of supporting facilities, the employee's efficacy for changes will be affected. Employees are not sure that they will be able to make changes because they will get difficulties from the lack of facilities that support their performance in these changes. 
Supervisor Control, where the company needs to set an objective standard of employee assessment. Establishing the same standards of evaluation between employees will disrupt employee confidence that the company will support each employee to make changes fairly. This is able to increase the employee support for changes that occur.

(Armenakis et al., 2007) explains that readiness in dealing with changes consists of beliefs, attitudes, and intentions towards the effort to change. Thus, the researcher describes readiness in facing further changes in the dimensions that shape it. Based on the results of measurements of beliefs, attitudes, and intentions dimensions, it was found that the beliefs dimension has the highest average value among other dimensions. Therefore, it can be concluded that employees have beliefs and preferences to support change, but their willingness to make a change is not in accordance with their beliefs and preferences. This can bring up aspects of change that employees are not prepared to face when implemented in the company. In further discussion, researchers tried to describe how beliefs, attitudes, and intentions dimensions illustrate employee readiness in dealing with changes in company. The researchers used a quadratic regression test to analyze the description of beliefs, attitudes, and intentions on readiness for changes.

Table 2. Model of Regression Readiness for Changes

\begin{tabular}{ll}
\hline Model & R Square \\
\hline 1 &, 538 \\
\hline
\end{tabular}

Table 3. Regression Coefficient of Readiness for Changes

\begin{tabular}{lll}
\hline Model & $\mathbf{t}$ & Sig. \\
\hline Beliefs & 5,684 & $\mathbf{. 0 0 0}$ \\
\hline Attitudes &, 508 & .612 \\
\hline Intentions & 1,968 & .052 \\
\hline
\end{tabular}

Based on the results of statistical analysis, it was found that the three dimensions can illustrate the readiness to deal with changes by $53.8 \%$, while the other $46.2 \%$ was described by other factors. In addition, it was found that beliefs are the dimension that can best describe the readiness to deal with change (Sig.> 0.05).

Employee beliefs showed a high tendency towards changes that occur in company. In other words, employees have confidence that change is needed and must be fulfilled, namely in the gap between the desired results and current conditions and changes can be made by themselves and their groups. 


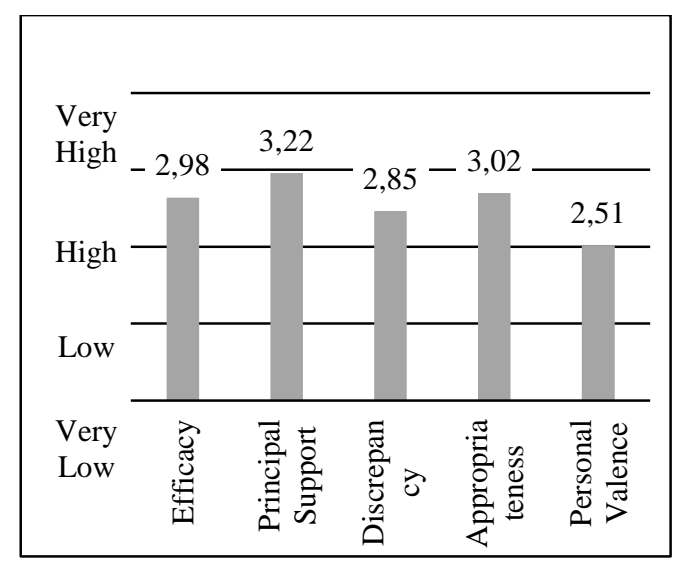

Fig.1. Beliefs sub-dimensions

These results are based on the table above which shows that efficacy, principal support, discrepancy, appropriateness, and personal valence conditions of employees with a high level as well. The quadratic regression test in analyzing the sub dimension of beliefs was also carried out to describe the condition of dimension beliefs.

Table 4. Beliefs Dimension Regression Models

\begin{tabular}{ll}
\hline Model & R Square \\
\hline 1 &, 999 \\
\hline
\end{tabular}

Table 5. Regression Coefficients of Beliefs Dimension

\begin{tabular}{lll}
\hline Model & t & Sig. \\
\hline Efficacy & 76,113 & $\mathbf{. 0 0 0}$ \\
\hline Principal Support & 76,678 & $\mathbf{. 0 0 0}$ \\
\hline Discrepancy & 77,213 & $\mathbf{. 0 0 0}$ \\
\hline Appropriateness & 88,363 & $\mathbf{. 0 0 0}$ \\
\hline Personal Valence & 68,297 & $\mathbf{. 0 0 0}$ \\
\hline
\end{tabular}

Based on the result of statistical analysis, it was found that these three dimensions can illustrate the readiness to deal with changes of $99.9 \%$, and all beliefs sub-dimensions can describe beliefs dimension significantly.

Employees who are ready to deal with changes are those who already have cognitive conditions who believe, are sensitive, and are willing to make changes. This means that employees need to have high beliefs, attitudes, and intentions for the changes that occur. With the presence of high beliefs, attitudes, and intentions in employees, a condition of change that is expected by the organization will be realized.

In this study, it was found that the majority of employees already had readiness in the face of changes. However, there were still a few aspects of change that are still not ready to be faced by them. This is shown from $4 \%$ of employees who were in very high category and $85 \%$ of employees in the high category.

Meanwhile, there are still few employees $(11 \%)$ who do not believe in, give preference, and are willing to make an effort to make changes. This is an indication of the unpreparedness of some employees in dealing with the changes that occur. Therefore, the company needs to 
take action to increase employee readiness in order that the company can realize the expected conditions of the changes that occur.

\section{Conclusion}

- The majority of employees have a high readiness in the face of changes

- Difference in degrees of beliefs, attitudes, and intentions shape employee readiness and unpreparedness in the face of changes.

- Beliefs are the variable that best describes the readiness to deal with changes.

- Employees with managerial positions have higher readiness than employees in staff positions and staff support.

- The emergence of employee resistance to change can be constrained by supervisor control, facilities, work time, job description, coordination, adaptation of government policies, rules or SOP aspects that need to be reviewed before being implemented in the company according to the employees.

\section{References}

[1] Armenakis, A. A., Harris, S. G., Cole, M. S., Lawrence Fillmer, J. and Self, D. R. (2007) 'A Top Management Team's Reactions to Organizational Transformation: The Diagnostic Benefits of Five Key Change Sentiments', Journal of Change Management, 7(3-4), pp. 273-290. doi: 10.1080/14697010701771014.

[2] Armenakis, A. A., Harris, S. G. and Mossholder, K. W. (1993) 'Creating Readiness for Organizational Change', Human Relations, 46(6), pp. 681-703. doi: 10.1177/001872679304600601.

[3] Hanpachern, C., Griego, O. V. and Morgan, G. A. (1998) 'An Extension of the Theory of Margin: A Framework for Assessing Readiness for Change.', Human Resource Development Quarterly, 9(4), pp. 339-500. Available at: https://eric.ed.gov/?id=EJ576677 (Accessed: 15 January 2019).

[4] Holt, D. T., Armenakis, A. A., Feild, H. S. and Harris, S. G. (2007) 'Readiness for organizational change: The systematic development of a scale', Journal of Applied Behavioral Science, 43(2), pp. 232-255. doi: 10.1177/0021886306295295.

[5] Jones, G. R. (2013) Organizational Theory, Design, and Change. 7th Global. Harlow, Essex: Pearson.

[6] Kunert, S. and Staar, H. (2018) 'Failure in Organizational Change', in, pp. 9-25. doi: 10.1007/978-3-319-72757-8_2.

[7] Rafferty, A. E., Jimmieson, N. L. and Armenakis, A. A. (2013) 'Change Readiness: A Multilevel Review', Journal of Management, 39(1), pp. 110-135. doi: 10.1177/0149206312457417.

[8] Rafferty, A. E. and Restubog, S. L. . (2006) 'hy Do Employees' Perceptions of their Organization's Change History Matter? The Role of Change Appraisals', Human Resource Management, pp. 1-18. doi: 10.1002/hrm.

[9] Sugiyono (2009) 'Metode Penelitian Administrasi dilengkapi Metode R\&D'. Bandung: Alfabeta.

[10] Vakola, M. (2013) 'Multilevel Readiness to Organizational Change: A Conceptual Approach', Journal of Change Management, 13(1), pp. 96-109. doi: 10.1080/14697017.2013.768436.

[11] Vakola, M. (2014) 'What's in there for me? Individual readiness to change and the 
perceived impact of organizational change', Leadership and Organization Development Journal, 35(3), pp. 195-209. doi: 10.1108/LODJ-05-2012-0064. 